\title{
PENINGKATAN KETERAMPILAN MENULIS SURAT DENGAN PENDEKATAN CONTEKSTUAL TEACHING \& LEARNING PADA SISWA KELAS IV
}

\author{
Marta Juriah, \\ Guru SDN 04 Kec. Nanga Pinoh Kab.Melawi
}

\begin{abstract}
This study aims to find out how much influence the contextual teaching and learning approach can improve the writing skills of letters grade IV students SDN 04 Nanga Pinoh. The type of research is Classroom Action Research designed by using cycle model by Kemmis and Mc Taggart. Where in the implementation of this PTK action consists of 4 stages, namely: planning, implementation of action, observation and reflection, with the aim to compare the value before the action and after the action. Technique of data collecting is done by observation observation and result of student learning test. The subjects of the study were the fourth grade students of SDN 04 Nanga Pinoh, which amounted to 27 people. There was an increase of learning achievement by using Contextual Teaching \& Learning approach of personal letter writing writing to fourth grade students of SDN 04 Nanga Pinoh. This is evident in the increase in the value of the initial test of 27 students by 64 with $63 \%$ of students experiencing completeness. In cycle I the average value obtained by 80 then in cycle II the average value obtained increased by 81 with $92 \%$ of students experiencing completeness in learning. Based on these data it can be seen that the contextual teaching and learning approach can improve the writing skill of grade 4 students of SDN 04 Nanga Pinoh.
\end{abstract}

Keywords: Contextual Teaching \& Learning Approach, Writing Skills

\section{PENDAHULUAN}

Guru adalah pendidik profesional dengan tugas utama mendidik, mengajar, membimbing, mengarahkan, melatih, menilai, dan mengevaluasi peserta didik pada pendidikan anak usia dini jalur pendidikan formal, pendidikan dasar, dan pendidikan menengah (UU Guru dan Dosen No.14 Tahun 2005 Pasal 1 Ayat 1). Berdasarkan hal tersebut seorang guru harus dapat mengelola proses pembelajaran dengan baik. Tujuan pendidikan akan tercapai apabila tercipta lingkungan belajar yang kondusif dan proses kegiatan belajar mengajar berjalan dengan lancer.

Salah satu kompetensi yang harus dimiliki guru sebagai seorang pendidik adalah kompetensi pedagogik. Di sini guru hendaknya mampu menguasai dan merancang pembelajaran yang sesuai dengan kondisi siswa sebagai peserta didiknya. Guru harus dapat mengelola pembelajaran dengan baik sehingga siswa akan lebih mudah memahami dan menerima pelajaran. Guru berperan sebagai fasilitator dalam proses pembelajaran.
Kegiatan belajar mengajar yang dilaksanakan hendaknya dapat melibatkan anak secara aktif, sehingga mereka dapat berkembang dengan optimal. Pembelajaran hendaknya dirancang dan disesuaikan dengan tingkat perkembangan anak. Anak usia Sekolah Dasar menurut Piaget termasuk dalam tahap operasional konkrit, dimana anak belum bisa untuk berpikir secara abstrak.

Tugas guru adalah merancang pembelajaran yang mudah ditangkap dan nyata bagi siswa. Guru yang kreatif adalah guru yang dapat memanfaatkan lingkungan sekitar sebagai sarana pembelajaran siswa (Darmodjo,1992 dalam http://belajarmenjadilebih.wordpress.com/tag/j ean-piaget/). Bahasa Indonesia sebagai bahasa nasional tidak mengikat para pemakainya untuk sesuai dengan kaidah dasar. Bahasa Indonesia digunakan secara nonresmi, santai, dan bebas. Yang dipentingkan dalam pergaulan antarwarga adalah makna yang disampaikan. Pemakai bahasa Indonesia dalam konteks bahasa nasional dapat dengan bebas 
menggunakan ujarannya baik secara lisan, tulis, maupun lewat kinestetiknya (Suyatno, 2004:6-7) Dalam Kurikulum Tingkat Satuan Pendidikan disebutkan bahwa mata pelajaran Bahasa Indonesia bertujuan salah satunya agar peserta didik memiliki kemampuan berkomunikasi secara efektif dan efisien sesuai dengan etika yang berlaku, baik secara lisan maupun tulis.

Meskipun zaman sudah modern, pergaulan dan komunikasi masyarakat makin mudah dilakukan baik melalui media seluler ataupun internet, namun komunikasi tulis (melalui surat) tidak lepas dalam kehidupan kita sehari-hari. Salah satu materi dalam mata pelajaran Bahasa Indonesia pada kelas IV adalah tentang menulis surat pribadi. Standar Kompetensi yang tertuang dalam KTSP adalah mengungkapkan pikiran, perasaan, dan informasi secara tertulis dalam bentuk percakapan, petunjuk, cerita, dan surat. Sedangkan kompetensi dasarnya adalah menulis surat untuk teman sebaya tentang pengalaman atau cita-cita dengan bahasa yang baik dan benar dan memperhatikan penggunaan ejaan (huruf besar, tanda titik, tanda koma dll). Untuk itu siswa dituntut untuk menguasai indikator dan tujuan pembelajaran Bahasa Indonesia berdasarkan Standar Kompetensi dan Kompetensi Dasar yang terdapat dalam Kurikulum Tingkat Satuan Pendidikan dan berlaku saat ini.

Berdasarkan pengamatan yang diperoleh, pembelajaran menulis surat yang dilakukan di SDN 04 Nanga Pinoh cenderung menggunakan pendekatan tekstual. Materi ajar dilakukan masih berdasarkan buku pegangan guru dan siswa. Proses pembelajaran berlangsung satu arah (Teacher Centered). Siswa kurang terlibat aktif dalam pembelajaran. Terlebih dalam menulis surat, para siswa masih banyak yang belum memahami bahasa surat. Mereka beranggapan bahwa bahasa surat sama dengan bahasa lisan yang dapat langsung terjadi pada saat itu. Selain itu, siswa mengalami kesulitan dalam menuangkan pikiran, perasaan, dan pengalaman mereka dalam bahasa surat karena mereka hanya sebatas berimajinasi dan tidak mengalaminya secara langsung. Menurut Elin
Rosaline (1998:3-7), terdapat dua kutub pembelajaran saat ini, yaitu behaviorisme dan konstruktivisme. Konstruktivisme adalah proses membangun atau menyusun pengetahuan baru dalam struktur pengetahuan siswa berdasarkan pengalaman. Menurut konstruktivisme, pengetahuan itu berasal dari luar, tapi dikonstruksi oleh dan dari dalam diri seseorang. Hal inilah yang kemudian melandasi pembelajaran kontekstual (Contekstual Teaching Learning/CTL).

Pembelajaran dengan model CTL pada dasarnya mendorong siswa agar bisa mengkonstruksi pengetahuannya melalui proses pengamatan dan pengalaman (Elin Rosaline, 1998:3-7). Siswa akan lebih mudah memahami materi pelajaran apabila mereka mengalaminya langsung dalam kehidupan sehari-hari. Materi pelajaran yang diperolehnya di sekolah dapat langsung diterapkan di lingkungannya. Pengalaman yang dilakukannya akan lebih bermakna daripada teori-teori yang ada. Siswa juga akan memperoleh pengetahuan dan pemahaman yang akan bertahan lebih lama karena mereka mengalami langsung dan terlibat aktif dalam pembelajaran dibandingkan dengan pembelajaran dengan metode ceramah (konvensional).

Keterampilan menulis surat dapat diasah dan ditingkatkan dengan penerapan pendekatan Contekstual Teaching Learning(CTL). Pendekatan CTL ini dapat meningkatkan pemahaman dan keterampilan siswa dalam menulis surat karena siswa dapat mengalami dan menerapkan langsung materi yang sedang dipelajarinya dalam kehidupan sehari-harinya. Dengan pengalaman langsung yang dilakukan oleh siswa, maka siswa akan merasa bahwa pelajaran ini penting dalam hidup mereka dan termotivasi untuk melakukannya. Siswa bisa mengkonstruksi pengetahuannya melalui proses pengamatan dan pengalamannya sendiri.

Perumusan masalah dalam penelitian ini adalah: 1) Bagaimanakah peningkatan keterampilan menulis surat pribadi pada siswa kelas IV SDN 04 Nanga Pinoh yang diajar menggunakan pendekatan Contekstual Teaching and Learning (CTL)? 2) Bagaimana 
pelaksanaan pembelajaran menulis surat pribadi dengan pendekatan Contekstual Teaching and Learning (CTL) pada siswa kelas IV SDN 04 Nanga Pinoh?

Sesuai dengan rumusan masalah di atas, penelitian ini bertujuan untuk: 1) Mendeskripsikan peningkatan keterampilan menulis surat pribadi pada siswa kelas IV SDN 04 Nanga Pinoh dengan menggunakan pendekatan Contekstual Teaching and Learning (CTL). 2) Mendeskripsikan pelaksanaan pembelajaran keterampilan menulis surat pribadi pada siswa kelas IV SDN 04 Nanga Pinoh dengan menggunakan pendekatan Contekstual Teaching and Learning (CTL).

\section{METODE}

Jenis penelitian yang dilakukan adalah penelitian tindakan kelas yang dilaksanakan dalam beberapa siklus, yaitu siklus I dan seterusnya. Tahap-tahap pelaksanaan meliputi perencanaan, pelaksanaan, pengamatan dan refleksi.

\section{Subjek dan Objek Penelitian}

Subjek adalah guru dan siswa. Guru akan melaksanakan penelitian tindakan kelas untuk meningkatkan keterampilan menulis surat pribadi dalam pembelajaran Bahasa Indonesia. Sedangkan siswa kelas IV SDN 04 Nanga Pinoh yang berjumlah 27 orang dengan siswa laki-laki dan 4 orang siswa perempuan yang akan di tingkatkan keterampilan menulis suratnya. Objek penelitian ini adalah menngkatkan keterampilan menulis surat pribadi kelas IV SDN 04 Nanga Pinoh dalam pembelajaran Bahasa Indonesia dengan menggunakan pendekatan contekstual teaching \& Learning (CTL).

Pada siklus I, persiapan yang dibuat adalah berupa pembuatan rencana pembelajaran, dan mempersiapkan instrumen penelitian yang diperlukan antara lain; mempersiapkan lembar observasi pelaksanaan pembelajaran dengan pendekatan CTL, RPP Bahasa Indonesia melalui pendekatan CTL, LKS, tes keterampilan menulis surat pribadi siswa yang nantinya akan selalu dipersiapkan guru setiap pelaksanaan proses pembelajaran, sesuai dengan materi pelajaran pada tiap pertemuan dalam tiap siklus. Rencana pembelajaran yang disusun mengacu pada kurikulum tingkat satuan pendidikan (KTSP) 2006.

\section{Pelaksanaan}

Pada tahap pelaksanaan tindakan ini peneliti melaksanakan proses pembelajaran sesuai dengan rencana yang sudah dipersiapkan pada tahap perencanaan, waktu yang digunakan untuk pemberian tindakan dalam satu siklus adalah disesuaikan dengan kompetensi dasar materi yang akan dibahas untuk siklus I dilaksanakan tiga kali pertemuan atau $6 \times 35$ menit ( $3 \times$ pertemuan), dan untuk siklus II dilaksanakan satu kali pertemuan atau 2 x 35 menit (1 x pertemuan). Pelaksanaan Tindakan pada Pertemuan Pertama Siklus I Pertemuan pertama pada siklus I dilaksanakan pada hari kamis, tanggal 18 Agustus 2016 mulai pukul 07.00 - 08.45 WIB. Pelaksanaan pertemuan kedua pada siklus I dilaksanakan pada hari Senin tanggal 23 Agustus 2016, pukul 07.35-08.45 WIB. Pelaksanaan pertemuan ketiga, hari Selasa, 30 Agustus 2016 dimulai pada pukul $07.35-08.45$ WIB. Pengamatan

Pengamatan terhadap penampilan siswa dilakukan untuk menilai aspek keterampilan siswa dalam menulis surat pribadi menggunakan pendekatan CTL. Dari hasil pengamatan diperoleh data bahwa pada kegiatan awal pembelajaran siswa sudah terlihat sedikit antusias mengikuti pembelajaran dan menyiapkan perlengkapan pembelajaran. Selain itu siswa sudah bisa memperhatikan pernyataan guru tentang materi yang akan dipelajari. Siswa berani bercerita pengalaman dan cita-citanya, meski dengan bimbingan guru. Bahasa yang digunakannya ada beberapa yang bercampur dengan Bahasa dayak. Penggunaan ejaan dan tanda baca sebagian besar siswa kurang teliti, sehingga terdapat ketidaktepatan pada kalimat-kalimat yang ada terutama penggunaan tanda titik dan huruf kapital. Pada kegiatan penutup, siswa sudah mulai mengerti akan fungsi surat dengan benar. Siswa sudah bisa merencanakan apa yang akan mereka tuliskan dalam membuat surat pribadi untuk temannya. Pada tahap mengemukakan 
gagasan atau menyimpulkan apa yang telah mereka pelajari, hanya sebagian siswa yang berani berbicara atau mengemukakan pendapat tanpa harus disuruh.

\section{Refleksi}

Pembelajaran tindakan siklus I dilaksanakan dengan memberikan siswa pengalaman yang nyata. Siswa diajak untuk praktek langsung dan dapat melakukan observasi serta tanya jawab dengan tokoh yang bersangkutan langsung dalam hal persuratan. Siswa dibawa masuk dalam dunia nyata, bukan lagi pembelajaran konvensional di dalam kelas. Untuk memperoleh data tentang tindakan siklus I dilakukan pengamatan, tes, dan dokumentasi dianalisis dan didiskusikan dengan pengamat diperoleh hal-hal sebagai berikut: (1) Pelaksanaan pembelajaran sudah berjalan sesuai dengan rencana pembelajaran namun belum optimal. (2) Dalam memberi bantuan diskusi kelompok, guru masih kelihatan kurang aktif dan kurang merata. Hal tersebut disebabkan belum terbiasanya melakukan pembelajaran dengan pendekatan CTL. (3) Berdasarkan hasil pengamatan menunjukkan bahwa guru perlu meningkatkan cara memotivasi siswa dalam mengeluarkan pendapat. (4) Hasil pengamatan tentang keterampilan menulis surat pribadi siswa selama proses pembelajaran perlu ditingkatkan karena belum semua terampil. (5) Siswa terlihat belum berani bertanya tentang masalah yang belum dipahaminya. (6) Pembelajaran pada siklus I memerlukan waktu yang lebih dari waktu yang telah direncanakan karena banyaknya materi yang dibahas. (7) Hasil tes menunjukkan bahwa nilai tes ratarata siswa sebagian besar sudah dalam keadaan tuntas akan tetapi masih ada lima siswa yang belum tuntas. (8) Hasil analisis tes akhir menunjukkan bahwa siswa masih belum teliti dalam menggunakan ejaan dan tanda baca. Hampir semua surat pribadi yang dibuat siswa terdapat kesalahan baik banyak maupun sedikit. (9) Secara keseluruhan siswa telah memahami bahasa dan struktur susunan menulis surat pribadi. (10) Kesan siswa dalam akhir siklus I mengungkapkan bahwa siswa sangat senang belajar dengan pendekatan CTL.

Dari hasil observasi, hasil tes tindakan, hasil analisis dan refleksi pada tindakan siklus I menunjukkan bahwa pembelajaran siklus I membutuhkan pengulangan pada tindakan siklus II untuk lebih memperkuat data dan memperbaiki hasil. Hal ini berarti bahwa pembelajaran pada siklus I perlu penyempurnaan sebagai berikut; (1) 1. Memotivasi siswa agar aktif berdiskusi dalam kelompok. (2) Guru diharapkan mampu memberi perhatian yang lebih kepada siswa untuk dapat memahami konsep melalui praktek langsung. (3) Untuk mengefektifkan waktu, maka pada dalam siklus kedua lebih ditekankan pada penggunaan ejaan dan tanda baca dalam menulis surat pribadi. (4) Membantu siswa agar terampil menuangkan gagasannya secara tertulis melalui surat. (5) Memberikan perhatian dan bimbingan yang lebih bagi siswa yang belum tuntas belajar.

\section{Siklus II \\ Perencanaan}

Perencanaan pembelajaran pada siklus II disusun bertujuan untuk menyempurnakan kekurangan-kekurangan pada siklus I agar pelaksanaan siklus II menjadi lebih baik. Pembelajaran pada siklus II tetap menggunakan pendekatan CTL, rencana tindakan pada siklus II akan dilakukan dalam satu kali pertemuan, yaitu pada tanggal 1 September 2016. Dari faktor guru telah dipersiapkan pembelajaran dengan menggunakan pendekatan CTL secara lebih baik. Guru membawa siswa untuk langsung mengalami dan berkorespondensi dengan temannya. Guru diharapkan mampu memotivasi siswa agar lebih berani dan kreatif dalam menuangkan pendapat dan gagasannya secara lisan maupun tertulis serta mempresentasikan hasil kerjanya ke depan kelas, sehingga akan tercipta suasana saling berbagi pendapat atau pengalaman dan pengetahuan.

\section{Pelaksanaan}

Pertemuan pada siklus II dilaksanakan pada hari Kamis, tanggal 1 September 2016 
pada pukul 07.00-0 WIB. Materi pokok pada pertemuan ini adalah penggunaan ejaan dan tanda baca dalam menulis surat pribadi dengan kompetensi dasar menulis surat untuk teman sebaya tentang pengalaman atau citacita dengan bahasa yang baik dan benar serta memperhatikan penggunaan ejaan (huruf besar, tanda titik, tanda koma dll). Pelaksanaan tindakan sama dengan pelaksanaan pada siklus I yang terdiri dari tiga tahapan yaitu tahap awal, tahap inti , dan tahap akhir.

\section{Pengamatan}

Dari hasil pengamatan diperoleh data bahwa pada awal pembelajaran siswa kelihatan sudah banyak peningkatan pada aspek bertanya dan keterlibatan secara aktif bekerja dalam kelompok. Sebagian besar siswa sudah sangat antusias dan berani untuk menampilkan hasil kerja kelompoknya ke depan kelas dan mempresentasikan dengan baik. Pada tahap kegiatan inti, siswa menyelesaikan masalah dalam kelompok secara bersama-sama tidak lagi terlihat individualnya. Dalam diskusi kelompok, sebagian besar siswa aktif melakukan kerja sama untuk menyelesaikan tugas kelompok yang diberikan, siswa yang lain membantu saat ada kesulitan yang ditemui oleh temannya.

\section{Refleksi}

Setelah tindakan dilakukan pada siklus II ini, proses pembelajaran dengan menggunakan pendekatan CTL sudah berkategori sangat baik. Keterlibatan guru dan siswa dalam pembelajaran menggunakan pendekatan CTL sudah berjalan seperti yang diharapkan, meskipun pada awalnya masih ditemui banyak kendala namun dengan perbaikan dalam pelaksanaan pembelajaran pada pertemuan selanjutnya mengalami peningkatan yang fluktuatif. Siswa yang pada awalnya masih belum memahami bagaimana struktur surat pribadi, cara mengungkapkan pangalaman/ cita-citanya melalui bahasa tertulis serta penggunaan ejaan dan tanda baca yang tepat dengan perlahan mengalami peningkatan. Dengan pembelajaran menggunakan pendekatan Contekstual Teaching Learning khususnya dalam pelajaran Bahasa Indonesia efektif digunakan guna peningkatan keterampilan menulis surat pribadi siswa kelas IV.

Dari hasil observasi, hasil tes tindakan, hasil analisis, dan refleksi pada tindakan siklus II menunjukkan bahwa sudah terjadi peningkatan keaktifan belajar yang signifikan, oleh karena itu dirasa cukup dan tidak perlu melanjutkan ke siklus berikutnya.

\section{HASIL DAN PEMBAHASAN \\ Hasil \\ Tindakan Siklus I}

Hasil tes akhir tindakan siklus I menunjukkan bahwa nilai pembelajaran sudah memenuhi kriteria keberhasilan yang telah ditetapkan. Nilai yang diperoleh siswa secara bertahap mengalami kenaikan. Dibandingkan dengan nilai pretest, nilai siswa mengalami kenaikan yang cukup besar. Dari hasil pertemuan kedua dan tes akhir, nilai siswa juga meningkat.

Berdasarkan hasil tes akhir tindakan siklus I nilai rata-rata siswa baik yaitu sebesar 80 kategori sangat baik. Namun, belum semua siswa tuntas dalam pembelajaran keterampilan menulis surat dengan pendekatan CTL. Masih ada beberapa anak yang mendapatkan nilai akhir pada siklus pertama di bawah Kriteria Ketuntasan Minimal (KKM) yaitu 65. Untuk lebih jelasnya dapat dilihat dalam tabel ketuntasan belajar siswa berikut :

Tabel 1

Persentase Ketuntasan Nilai Keterampilan Menulis Surat Pribadi pada Tes Akhir dengan Pendekatan CTL

\begin{tabular}{ccccc}
\hline \multicolumn{3}{c}{ Ketuntasan } & & \\
\cline { 1 - 3 } Tuntas & $\%$ & Belum Tuntas & $\%$ & Prestasi Rata-rata Kelas \\
\hline 25 & 92 & 2 & 8 & 80 \\
\hline
\end{tabular}


Berdasarkan tabel ketuntasan belajar di atas sudah banyak siswa yang mencapai nilai lebih dari KKM, namun masih ada dua siswa yang belum mencapai KKM dan belum tuntas belajarnya. Dari jumlah 27 siswa kelas IVB, 25 siswa atau 92\% sudah tuntas dan 2 siswa atau $8 \%$ belum tuntas.

\section{Hasil Tindakan Siklus II}

Hasil tes akhir tindakan siklus II menunjukkan bahwa hasil pembelajaran sudah sesuai dengan kriteria keberhasilan yang telah ditetapkan. Bahkan hampir secara keseluruhan siswa mendapat nilai yang sangat memuaskan.

Tabel 2

Persentase Ketuntasan Nilai Keterampilan Menulis Surat Pribadi Siklus II

\begin{tabular}{ccccc}
\hline \multicolumn{3}{c}{ Ketuntasan } & \\
\cline { 1 - 3 } Tuntas & $\%$ & Belum Tuntas & $\%$ & Prestasi Rata-rata Kelas \\
\hline 25 & 92 & 2 & 8 & 81 \\
\hline
\end{tabular}

Pada siklus II, ada peningkatan skor/ nilai tes akhir tindakan siswa jika dibandingkan dengan skor hasil tes akhir tindakan sebelumnya. Dari jumlah keseluruhan siswa 92\% masuk dalam kategori tuntas belajar dan hanya $8 \%$ (dua siswa yang tidak tuntas belajar). Hal ini menunjukkan bahwa pada siklus II siswa sudah mampu berkonsentrasi dan memahami materi belajar serta aktif dalam proses pembelajaran melalui pendekatan CTL.

Dari hasil observasi, hasil tes tindakan, hasil analisis, dan refleksi pada tindakan siklus II menunjukkan bahwa sudah terjadi peningkatan keaktifan belajar yang signifikan, oleh karena itu dirasa cukup dan tidak perlu melanjutkan ke siklus berikutnya.

\section{Pembahasan}

Penampilan Guru dan Siswa dengan Menerapkan Pendekatan CTL pada Siklus I. Pada siklus I, hasil observasi terhadap aktivitas belajar siswa dan guru dengan menerapkan pendekatan CTL pada pembelajaran keterampilan menulis surat cukup baik. Tahap pendahuluan guru sudah berusaha menarik perhatian siswa untuk belajar yaitu dengan apersepsi di awal pembelajaran. Siswa menyanyikan lagu berjudul "Pak Pos" dan juga mengamati berbagai macam jenis perangko. Tetapi pada tahap awal siswa masih kurang konsentrasi dan kurang memperhatikan terhadap penjelasan yang disampaikan guru karena mereka melihat adanya perbedaan strategi yang diterapkan guru dalam pembelajaran biasanya. Disamping itu, siswa masih membawa kebiasaan mereka dalam pembelajaran yaitu mereka terpaku melihat buku dan penjelasan guru saja. Pada kegiatan awal pembelajaran guru menyampaikan tujuan pembelajaran.

Setelah melakukan eksplorasi terhadap kemampuan dan pengetahuan siswa, serta menjelaskan kegiatan yang akan dilakukan selanjutnya, guru membagi siswa ke dalam 8 kelompok dari jumlah\keseluruhan siswa 27 orang. Setelah siswa dibagikan ke dalam kelompok maka guru meminta mereka duduk dalam kelompoknya masingmasing. Setiap kelompok menyelesaikan tugas kelompok yang dibutuhkan dalam kegiatan diskusi/ kerja kelompok. Kegiatan inti pembelajaran adalah guru membagikan LKS kepada setiap kelompok dan meminta siswa menyelesaikan tugas berdasarkan petunjuk dalam LKS. Selain itu, untuk memperjelas maka guru menyampaikan petunjuk pengisian LKS dan melakukan 
peragaan melalui kegiatan contoh yang diberikan oleh guru. Saat kerja kelompok dimulai guru juga membimbing siswa yang mengalami kesulitan dan meminta siswa untuk menanyakan hal-hal yang masih kurang dipahami. Dalam kegiatan inti pembelajaran juga disampaikan materi pembelajaran yang sudah dirancang pada pertemuan yang bersangkutan dan pemberian tugas individu atau kelompok yang diberikan secara langsung dalam setiap pembelajaran. Guru memotivasi siswa agar lebih giat dalam pembelajaran terutama dalam menyelesaikan tugas-tugas.

Hasil refleksi siklus pertama dinyatakan baik akan tetapi belum memenuhi kriteria keberhasilan yang diharapkan oleh karena kurang optimalnya rancangan dan penerapannya dalam pembelajaran, guru dan siswa kelas IV belum terbiasa menggunakan pendekatan pembelajaran Bahasa Indonesia dengan pendekatan CTL. Pada kegiatan ini siswa diminta melaporkan hasil kerja kelompoknya ke depan kelas, akan tetapi belum ada yang berani tampil dengan inisiatif sendiri tanpa harus disuruh oleh guru. Siswa merasa malu untuk tampil ke depan kelas utuk mempresentasikan kerja kelompoknya. Refleksi dan analisis tindakan pada siklus I nampaknya indikator keberhasilan siswa masih belum terpenuhi. Keaktifan siswa dalam npembelajaran masih dalam kategori cukup, belum semua siswa terlibat dalam pembelajaran yang dilaksanakan. Siswa juga kurang maksimal dalam melakukan tanya jawab dengan tokoh/ ahli di bidangnya (Pak Pos) karena terbatasnya waktu yang disediakan. Pada siklus I ini, persentase terhadap kegiatan guru dan siswa dalam pembelajaran menggunakan pendekatan CTL berdasarkan tabel analisis sebesar 72,33 atau masuk kategori baik Oleh karena itu, guru kolaborator dan peneliti secara bersama berdiskusi untukn mengambil langkah selanjutnya.
2. Penampilan Guru dan Siswa dengan Menerapkan Pendekatan CTL pada Siklus II.

Dari hasil pengamatan dan evaluasi terhadap penggunaan pendekatan CTL dalam pembelajaran keterampilan menulis surat pada siklus II, tahap pendahuluan guru sudah sangat berusaha untuk menarik perhatian siswa lebih baik lagi untuk belajar. Siswa diajak untuk menyanyikan lagu "Paman Datang" kemudian dari sana kegiatan belajar siswa dilanjutkan dengan berbagi cerita dan pengalaman masing-masing siswa. Hal ini dimaksudkan untuk mengaitkan pengetahuan siswa dengan kehidupan nyata agar siswa lebih mudah memahami materi pelajaran. Setelah membuka dan melakukan apersepsi, kegiatan inti pada pembelajaran adalah menyampaikan materi pembelajaran yang sudah dirancang pada pertemuan yang bersangkutan dan untuk pemberian tugas langsung (agar siswa aktif) dalam setiap pembelajaran.

Sedangkan, pada kegiatan kerja kelompok guru memotivasi siswa dan meminta siswa agar tidak ragu ataupun malu lagi untuk bertanya kepada guru ataupun teman yang dianggap mampu. Berdasarkan hasil refleksi dan analisis data selama proses pembelajaran pada siklus II, menunjukkan bahwa penerapan CTL sudah berjalan sangat baik. Siswa sudah sangat aktif dalam mengikuti kegiatan pembelajaran dan rata-rata sebagian besar siswa sudah terlihat berpartisipasi dalam menyelesaikan tugas-tugas yang diberikan. Pada siklus II menunjukkan bahwa siswa sudah terlihat aktif bertanya baik kepada guru maupun temannya, dan bersedia melaporkan hasil kerja kelompok dengan inisiatifnya sendiri. Peningkatan yang lain adalah siswa sudah mulai berani menanggapi dan memberi komentar terhadap hasil kerja kelompok lain. Pada siklus II, indikator pelaksanaan pembelajaran menggunakan pendekatan 
CTL masuk dalam kategori sangat baik atau sebesar 91,5.

3. Keterampilan Siswa Menulis Surat Penelitian tindakan kelas ini dilakukan untuk meningkatkan keterampilan siswa dalam menulis surat pribadi dengan teman sebaya tentang pengalaman atau cita-cita sesuai dengan kompetesi pelajaran Bahasa Indonesia kelas IV. Setelah dilakukan penelitian tindakan kelas melalui dua siklus dan empat kali pertemuan (siklus I, tiga kali pertemuan, dan siklus II, satu kali pertemuan), terlihat peningkatan yang signifikan terhadap keterampilan siswa dalam menulis surat pribadi. Dalam proses pembelajaran dengan menggunakan pendekatan CTL, terlihat adanya peningkatan pada perhatian dan konsentrasi siswa dalam pembelajaran, kemampuan siswa dalam berkomunikasi dengan teman dan guru, keberanian siswa mengemukakan pendapat dan mengajukan pertanyaan, keterampilan siswa menuangkan pikiran dan perasaan, ketekunan siswa dalam bekerja, kemampuan menggunakan waktu secara efektif, dan kemampuan bekerjasama dalam kelompok. Peningkatan keterampilan menulis surat pribadi siswa selama dua siklus dapat dijelaskan sebagai berikut.

a) Keterampilan Menulis Surat Pribadi pada Siklus I

Pelaksanaan pembelajaran dengan menggunakan pendekatan CTL pada siklus I pada pelajaran Bahasa Indonesia dengan materi pokok keterampilan menulis surat berjalan dengan cukup baik. Pendekatan CTL mengharapkan siswa dapat mengaitkan pembelajaran dengan kehidupan nyata yang dialami sehari-hari. Akan tetapi, karena siswa belum terbiasa menggunakan metode dan pembelajaran CTL, maka menyebabkan proses pembelajaran dengan menggunakan pendekatan CTL pada siklus I hanya dapat digolongkan ke dalam kategori terampil. Hasil observasi terhadap keterampilan menulis surat pribadi siswa pada siklus I diperoleh pesentase sebesar 81,25 dengan kategori terampil. Keterampilan menulis surat pribadi siswa ini didukung dengan hasil akhir siswa dalam menulis surat pribadi.

Berdasarkan hasil tes akhir (post test) tindakan siklus I, diperoleh ratarata kelas sebesar 80 dengan nilai tertinggi adalah 92 dan nilai terendahnya adalah 50,00. Dengan hasil tersebut belum bisa dikatakan berhasil. Dari keseluruhan jumlah siswa, 25 siswa (92\%) sudah tuntas dan 2 siswa (8\%) belum tuntas.

Kelengkapan unsur dalam surat, seperti tanggal, alamat, salam pembuka, pembuka, isi, penutup, dan tanda tangan sudah dapat dipahami oleh para siswa. Siswa juga sudah mulai bisa mengungkapkan pendapat dan pengalamannya secara tertulis dalam surat. Namun, masih ada beberapa siswa yang bahasanya masih kaku dalam mengungkapkan pikiran dan pengalamannya. Selain itu, sebagian besar kesalahan siswa terletak dalam penggunaan ejaan dan tanda bacanya yang belum tepat. Penggunaan tanda baca titik, koma dan huruf kapital masih banyak ditemui. Selanjutnya, untuk memperbaiki dan meningkatkan keterampilan siswa dalam menulis surat pribadi akan diadakan tindakan parbaikan dalam siklus II agar nilai siswa bisa masuk dalam kategori sangat terampil.

b) Keterampilan Menulis Surat Pribadi pada Siklus II

Setelah diadakan refleksi dan
perbaikan tindakan pelaksanaan
proses pembelajaran keterampilan
menulis surat pribadi dengan
menggunakan pendekatan CTL pada
siklus II terjadi peningkatan pada
keterampilan siswa yang r sangat
signifikan. Guru mulai aktif


memberikan bimbingan kepada siswa. Dan sebagai timbal baliknya, siswa mengikuti pembelajaran dengan lebih aktif baik dalam hal bertanya maupun mengemukakan pendapat, selain itu siswa juga terlihat lebih memperhatikan dan konsentrasi dalam mengikuti kegiatan pembelajaran. Kegiatan inti pembelajaran difokuskan dalam penggunaan ejaan dan tanda baca dalam surat pribadi. Berdasarkan hasil observasi terhadap keterampilan menulis surat pribadi oleh dua observer diperoleh persentase rata-rata sebesar 81,25 , berada dalam rentang 80 - 100 masuk dalam kategori sangat terampil. Sejalan dengan hal tersebut, tujuan yang ingin dicapai sudah sesuai dengan yang diharapkan. Perolehan nilai rata-rata meningkat menjadi dari 80 menjadi 81. Akan tetapi belum 100\% siswa tuntas, hanya $92 \%$ siswa yang masuk kriteria belajar tuntas, karena ada dua orang siswa yang mendapat nilai 50. Kedua siswa tersebut dari awal kelas IV dalam hal menulis memang belum bisa rapi. Penggunaan huruf kapital belum dapat menerapkan. Semua kalimat ditulis dalam huruf kecil semua. Akan tetapi melalui pelajaran ini, mereka sudah mulai menggunakan huruf kapital meskipun belum semuanya tepat. Dengan hasil tersebut, maka tujuan dari penelitian tindakan kelas untuk meningkatkan keterampilan menulis surat pribadi dengan menggunakan pendekatan CTL tercapai. Selain itu juga dapat dilihat prestasi siswa juga mengalami peningkatan.

\section{KESIMPULAN DAN SARAN}

Berdasarkan dari hasil penelitian dapat ditarik kesimpulan bahwa melalui pendekatan CTL dalam pembelajaran keterampilan menulis surat pribadi dapat berjalan sesuai tujuan yang diharapkan (aktif dan efektif). Dalam hal ini menunjukkan bahwa peningkatan terjadi dari satu siklus ke siklus selanjutnya dari segi keterampilan siswa yang mengarah pada peningkatan dalam segi prestasi belajarnya juga. Setelah data dianalisis mengenai penerapan pembelajaran melalui pendekatan CTL yang dilakukan guru ternyata mengalami peningkatan dari siklus I hingga siklus II.

\section{DAFTAR RUJUKAN}

Darmodjo. (1992). Karakteristik Anak Usia SD. Diakses dari http://belajarmenjadilebih.wordpre ss.com/tag/jean-piaget/.pada tanggal 1 September 2016,

Fianzoner. (2009). Manfaat Menulis

Surat. Diakses dari

http://fianzoner.blogspot.com/2016/

01/manfaat-menulis.html. pada tanggal 2/9/2016.

http://www.anneahira.com/pengertianketerampilan-menulis.htm diakses pada tanggal 1/9/2016

Susanto, Ahmad, 2014 , Teori Belajar \& Pembelajaan di Sekolah Dasar, Kencana, Jakarta.

Tarigan, 2014, Menulis Sebagai Suatu Keterampilan Bahasa, Angkasa: Bandung 